\title{
Lithospheric mantle growth around cratons: A Re-Os isotope study of peridotite xenoliths from East Griqualand
}

\author{
D.G. Pearson ${ }^{1}$, Carlson. R.W. ${ }^{2}$, Boyd, F.R ${ }^{3}$, Shirey, S.B. ${ }^{2}$ and Nixon, P.H. ${ }^{4}$ \\ 1 Department of Geological Sciences, Durham University, South Rd, Durham, DH1 3LE. U.K. \\ 2. Department of Terrestrial Magnetism, Carnegie Institution of Washington, 5241 Broad Branch Rd. N.W. \\ Washington, DC 20015, U.S.A. \\ 3 Geophysical Laboratory, Carnegie Institution of Washington, 5251 Broad Branch Rd, N.W. \\ Washington. DC 20015, U.S.A. \\ 4 School of Earth Sciences, Leeds University, Leeds, LS29JT, U.K.
}

\section{Introduction}

A growing data base of Re-Os isotope measurements on peridotite xenoliths erupted by kimberlites through the Kaapvaal craton has greatly improved our knowledge of how cratonic lithosphere evolves (Walker et al, 1989; Pearson et al, 1995; Carlson et al, this vol.). Similar data for the lithosphere around the craton margins is scarce, with only one study of Namibian peridotites, erupted well off the exposed margin of the craton (Pearson et al, 1994). Such samples are of interest because they have the potential to provide information on (i) how the cratonic crust may over-ride the lithospheric mantle, and its obvious implications for diamond exploration (ii) the physical nature of the transition from Archaean to post-Archaean lithospheric mantle and (iii) any secular variation in the processes that lead to the formation of lithospheric mantle on and around cratons. To answer some of these questions we have studied a suite of peridotite ${ }^{-}$xenoliths erupted close to the S.E. margin of the Kaapvaal craton in East Griqualand.

\section{Samples: Petrography and mineral compositions}

The xenolith samples were collected from the Ramatseliso. Clarkton and Abbotsford kimberlites in East Griqualand. along the S.E. border with Lesotho. These kimberlites erupt through crust underlain by the Namaqua-Natal Mobile Belt and range in age from 150 to $194 \mathrm{Ma}$ in the basis of zircon ages (Boyd and Nixon, 1979). Mantle xenoliths include lherzolites, megacrysts, veined and metasomatised dunites and ilmenite-orthopyroxenites (Boyd and Nixon, 1979). As with cratonic samples, the suite may be divided up on the basis of pyroxene-solvus thermometry into a high-T and low-T suite, with the compositional break at $1100 \mathrm{C}$. There is general correspondence between low-T samples having coarse, equigranular textures and high- $\mathrm{T}$ samples being deformed, although some coarse samples have high equilibration temperatures (Nixon and Boyd, 1979). The low-T samples have mean olivine mg-numbers of 92.1, intermediate between the mean for Kaapvaal low- $T$ peridotites (92.8) and Namibian low-T peridotites (91.8) perhaps indicating some transitional character in the samples much closer to the known craton margin. 


\section{Re-Os isotope results and implications}

A suite of 19 peridotite xenoliths have been analysed for Os isotope compositions. Os contents span a similar range to cratonic peridotites (1 to $4 \mathrm{ppb}$ ) although some samples appear to have anomalously low Os $(0.2 \mathrm{ppb})$. Os isotope ratios a also variable, ${ }^{187} \mathrm{Os} /{ }^{188} \mathrm{Os}=0.12475$ to 0.11199 but do not reach the very unradiogenic values seen in cratonic peridotite suites (Pearson et al. 1995: Carlson et al, this vol.). Using the $\mathrm{T}_{\mathrm{RD}}$ approach (see et al, this vol.) the East Griqualand suite give Re depletion model ages in the range between present-day (probably metasomatised samples) and 2.3 Ga, i.e., slightly older, but within error of the ages reported by Pearson et al (1994) for the Namibian suite. The mean $T_{R D}$ age for the East Griqualand suite is slightly higher than that of the Namibian peridotites, again possibly hinting at some transitional character between cratonic samples and the more remote-from craton Namibian peridotites. However, there is no clear indication of an Archaean age for any east Griqualand peridotite, suggesting a sharp transition at the SE craton margin from peridotites with some of the oldest $T_{\mathrm{RD}}$ ages on craton $(3.3 \mathrm{Ga})$ to Proterozoic mantle. over a very short distance. The results for circum-cratonic peridotites to-date indicate that the craton margin at mantle depths is sharply defined and that the apparently younger. circum-cratonic lithosphere is of different petrological and chemical nature. being less refractory. These results support similar conclusions made on the basis of trace element analyses of mineral concentrates in kimberlites (Griffin et al, 1998). Finally, the Proterozoic ages for the East Griqualand peridotite suite confirm the general coherence between crust and mantle ages on- and off-craton (Fig. 1).

\section{References}

Boyd, F.F., and Nixon, P.H., 1979, Garnet lherzolite xenoliths from the kimberlites of East Griqualand, South Africa: Ann. Report Geophys. Lab. p. 488- 492.

Carlson, R.W.. Pearson, D.G., Boyd, F.R.. Shirey, S.B., Irvibe, G., Menzies, A.H., and Gurney, J.J., 1998. Regional age variation of the southern African mantle: Significance for models of lithospheric mantle formation: This vol.

Griffin, W.L.. O’Reilly, S.Y., Ryan, C.G., Gaul, O., and Ionov, D.A., 1998, Secular variation in the composition of subcontinental lithospheric mantle: Geophysical and Geodynamic implications: In press, in AGU Special monograph.

Pearson D. G., Boyd F. R., Koal, K., Hoal, B., Nixon, P.H., and Rogers, N.W., 1994, A Re-Os isotopic and petrological study of Namibian peridotites: contrasting petrogenesis and composition of on- and off-craton lithospheric mantle: Min Mag., 58A, p. 703-704.

Pearson, D.G., Carlson, R.W., Shirey, S.B., Boyd, F.R., and Nixon, P.H., 1995. The stabilisation of Archaean lithospheric mantle: A re-Os isotope study of peridotite xenoliths from the Kaapvaal craton: Earth Planet. Sci. Lett. 134, p.341-357.

Walker, R.J., Carlson, R.W., Shirey, S.B., and Boyd, F.R., 1989, Os, Sr, Nd, and Pb isotope systematics of southern African peridotite xenoliths: Implications for the chemical evolution of the subcontinental mantle: Geochim. Cosmochim. Acta., 53, 1583-1595. 

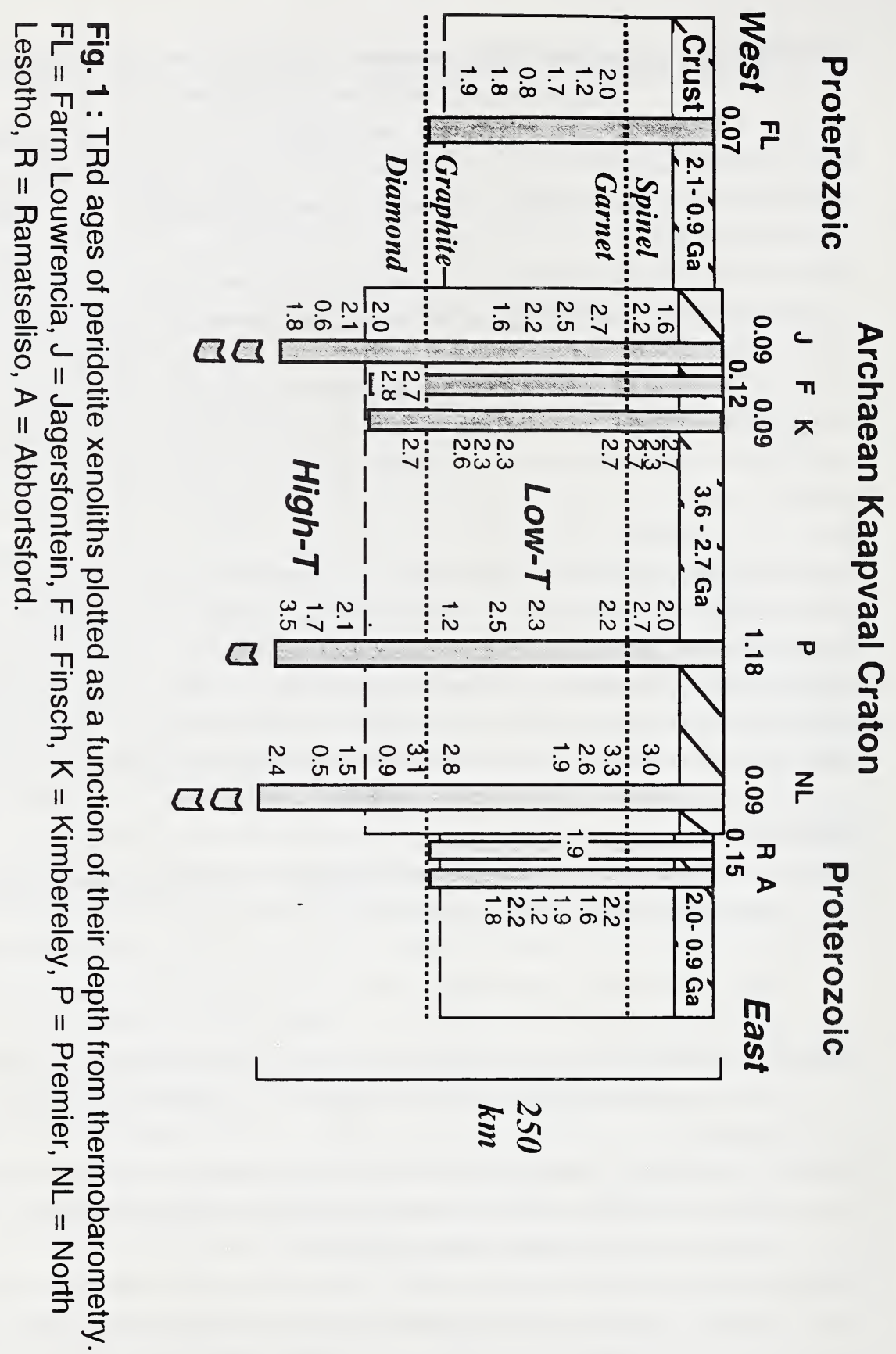